\title{
Poor Association of Bordetella Bronchiseptica Infection with Kennel Cough in Dogs in Northern India
}

\author{
Monika Bhardwaj, Bhoj Raj Singh", Sandeep Kumar, Abhijit M Pawde \\ Indian Veterinary Research Institute (IVRI), Izatnagar-243122, Bareilly, India \\ *Corresponding Author: brs1762@gmail.com
}

Copyright (C) 2013 Horizon Research Publishing All rights reserved.

\begin{abstract}
In the study nasal and throat swabs were collected from 78 apparently healthy and 69 cases of kennel cough from dogs of different age, sex, breed and places and analysed for presence of Bordetella bronchiseptica through bacterial isolation and multiplex PCR (mPCR). The pathogen could be isolated from an apparently healthy Labrador bitch while with mPCR, 7 (4.76\%, 4 from healthy dogs and 3 from sick dogs) samples were positive for genus specific amplicon and three $(2.04 \%$, one from healthy and two from sick Labrador bitches) were positive for $B$. bronchiseptica species specific amplicons. The kennel cough had no significant association $(\mathrm{p}, 0.49)$ with the detection of B. bronchiseptica but sex ( $\mathrm{p}, 0.03)$ appeared to be the significant predisposing factors associated with the infection.
\end{abstract}

Keywords Kennel Cough, Bordetella Bronchiseptica, Dog, Bitch

\section{Introduction}

Contagious respiratory tract infections in dogs are commonly diagnosed as canine infectious tracheobronchitis or kennel cough. Kennel cough affects dogs of all ages and breeds $[1,2]$. Of the several pathogens associated with kennel cough Bordetella bronchiseptica is considered to be the most important one [3, 4]. Bordetella bronchiseptica, a zoonotic respiratory pathogen, causes several other disease syndromes in human and other animals $[5,6]$. It is world-wide in occurrence but its status is little understood in India [7, 8]. Thus to understand the association of $B$. bronchiseptica with kennel cough in dogs this pilot study was undertaken.

\section{Materials and Methods}

In the study, nasal and throat swabs were collected from 78 apparently healthy and 69 cases of kennel cough from dogs of different age, sex and breed (Table. 1). The swabs were processed for bacterial isolation and also for detection of DNA of $B$. bronchiseptica with multiplex PCR standardized in the study. For isolation of B. bronchiseptica, swabs were resuscitated in $5 \mathrm{ml}$ buffered peptone water (Hi-Media, Mumbai) for $6-8 \mathrm{~h}$ at $37^{\circ} \mathrm{C}$ and then the growth was streaked on to blood agar (Hi-Media) and MacConkey lactose agar (Hi-Media) plates and incubated for 24-48 h at $37^{\circ} \mathrm{C}$. One $\mathrm{ml}$ of the growth from peptone water tube was transferred into eppendorf tube and kept in water bath at $100^{\circ} \mathrm{C}$ for $10 \mathrm{~min}$. Thereafter, the eppendorf was transferred to $-20^{\circ} \mathrm{C}$ for $10 \mathrm{~min}$, and centrifuged at $5000 \mathrm{rpm}$ for $5 \mathrm{~min}$ to collect supernatant. The supernatant was stored at $-20^{\circ} \mathrm{C}$ till used in polymerase chain reaction (PCR) as template to detect B. bronchiseptica. Typical, flat, non-haemolytic, oxidase and catalase positive colonies were characterised [9] on the basis of phenotypic biochemical and morphological characteristics. The isolates positive for urease and nitratase production and citrate utilization and negative for fermentation of sugars, production of gelatinase, DNase, indole and $\mathrm{H}_{2} \mathrm{~S}$ was identified as $B$. bronchiseptica $[10,11]$.

For detection of $B$. bronchiseptica DNA, multiplex-PCR was carried out in thermal cycler (Eppendorf, Germany) by using $5 \mu \mathrm{l}$ of template and one set of in house designed genus specific primers (Table. 2) and two sets of species specific primers $[12,13]$. The PCR amplification was carried out with an initial denaturation at $95^{\circ} \mathrm{C}$ for $10 \mathrm{~min}, 35$ cycles of denaturation at $94{ }^{\circ} \mathrm{C}$ for $30 \mathrm{~s}$, annealing at $53{ }^{\circ} \mathrm{C}$ for $30 \mathrm{~s}$ and extension at $72{ }^{\circ} \mathrm{C}$ for $45 \mathrm{~s}$ followed by a final extension step at $72{ }^{\circ} \mathrm{C}$ for $7 \mathrm{~min}$. Amplicons, $324 \mathrm{bp}$ (from alc gene) for genus specificity, 237 bp (from fla gene) and 425 bp (from fim gene) for species specificity, were visualized under UV light after electrophoresis on 1\% agarose gel (IBI scientific, Peosta Lowa) with $10 \mathrm{mg} / \mathrm{ml}$ ethidium bromide at 100 volts using $1 \times$ TBE electrophoresis buffer (Bio Basic Inc.).

Bordetella bronchiseptica strain (MTCC 6838) available in the laboratory was used in the study as control in all procedures for detection of the pathogen in clinical samples. The multiplex-PCR (mPCR) standardized in the study was sensitive to detect up to $5 \mathrm{cfu}$ of $B$. bronchiseptica (Fig. 1) and was specific as it did not yielded any amplicon using template from cultures of other common respiratory pathogens including E. coli, Pseudomonas alcaligenes, Pasteurella multocida, Streptococcus pyogenes and Staphylococcus aureus (Fig. 2). 
Table 1. Detection of Bordetella bronchiseptic from deep nasal and throat samples of apparently healthy and dogs suffering from kennel cough.

\begin{tabular}{|c|c|c|c|c|c|c|c|c|}
\hline \multirow{2}{*}{$\begin{array}{l}\text { Breed of the } \\
\text { dog }\end{array}$} & \multicolumn{2}{|c|}{ Sex } & \multirow{2}{*}{$\begin{array}{l}\text { Age } \\
\text { (yrs) }\end{array}$} & \multicolumn{2}{|c|}{$\begin{array}{c}\text { Health status } \\
\text { (numbers) }\end{array}$} & \multirow{2}{*}{$\begin{array}{l}\text { Positive for } \\
\text { isolation } \\
(\%)\end{array}$} & \multirow{2}{*}{$\begin{array}{c}\text { Positive with } \\
\text { PCR for genus } \\
\text { specific amplicon } \\
(\%)\end{array}$} & \multirow{2}{*}{$\begin{array}{c}\text { Positive with } \\
\text { PCR for species } \\
\text { specific } \\
\text { amplicon }(\%)\end{array}$} \\
\hline & Male & Female & & Sick & Healthy & & & \\
\hline Beagle & 0 & 7 & 1 to 4 & 4 & 3 & 0.0 & 0.0 & 0.0 \\
\hline Boxer & 2 & 0 & 1 to 3 & 1 & 1 & 0.0 & 0.0 & 0.0 \\
\hline Bull Mastiff & 1 & 0 & $<1$ & 0 & 1 & 0.0 & 0.0 & 0.0 \\
\hline Doberman & 5 & 0 & 1 to 7 & 3 & 2 & 0.0 & 0.0 & 0.0 \\
\hline $\begin{array}{l}\text { German } \\
\text { Shepherd }\end{array}$ & 9 & 7 & $<1$ to 9 & 6 & 10 & 0.0 & 0.0 & 0.0 \\
\hline Great Dane & 4 & 0 & 6 to 4 & 3 & 1 & 0.0 & 0.0 & 0.0 \\
\hline Labrador & 24 & 22 & $<1$ to 7 & 20 & 26 & $1(2.17)$ & $5(10.86)$ & $3(6.52)$ \\
\hline Mongrel & 12 & 5 & $\begin{array}{c}<1 \text { to } \\
14\end{array}$ & 6 & 11 & 0.0 & $1(5.88)$ & 0.0 \\
\hline $\begin{array}{c}\text { Napoleon } \\
\text { mastiff }\end{array}$ & 1 & 0 & $<1$ & 0 & 1 & 0.0 & 0.0 & 0.0 \\
\hline Pomeranian & 11 & 10 & $\begin{array}{c}<1 \text { to } \\
13\end{array}$ & 12 & 9 & 0.0 & 0.0 & 0.0 \\
\hline Pug & 6 & 3 & $<1$ to 3 & 2 & 7 & 0.0 & 0.0 & 0.0 \\
\hline Rottweiler & 6 & 0 & 1 to 6 & 3 & 3 & 0.0 & $1(16.66)$ & 0.0 \\
\hline Spaniel & 1 & 0 & 5 & 0 & 1 & 0.0 & 0.0 & 0.0 \\
\hline pitz & 5 & 5 & 2 to 10 & 8 & 2 & 0.0 & 0.0 & 0.0 \\
\hline Terrier & 1 & 0 & $<1$ & 1 & 0 & 0.0 & 0.0 & 0.0 \\
\hline Total & 88 & 59 & & 69 & 78 & $1(0.68)$ & $7(4.76)$ & $3(2.04)$ \\
\hline
\end{tabular}

Table 2. List of genus specific and species specific primers used in the study for Bordetella bronchiseptica

\begin{tabular}{|c|c|c|c|}
\hline Name of primers & Sequence $5^{\prime}-3^{\prime}$ & Product length (bp) & References \\
\hline \multicolumn{4}{|c|}{ Genus specific primers designed from alc gene } \\
\hline A643BBalc-F & GCCGACCCACGCAGCGAATAT & \multirow{2}{*}{213} & \multirow{2}{*}{ This study } \\
\hline A856Bbalc-R & GGCCGGTGACGAGATAGCTGTG & & \\
\hline B688Bbalc-F & ACCAACCGCATTTATTCCTACTA & \multirow{2}{*}{324} & \multirow{2}{*}{ This study } \\
\hline B1012Bbalc-R & GGCCCTGGAGTTCGTATTTATG & & \\
\hline \multicolumn{4}{|c|}{ Species specific primers for B. bronchiseptica } \\
\hline 425BBfim-1 F & TGAACAATGGCGTGAAAGC & \multirow{2}{*}{425} & \multirow{2}{*}{ Xin et al., 2008} \\
\hline 425BBfim-2 R & TCGATAGTAGGACG & & \\
\hline 237BBFla $4 \mathrm{~F}$ & TGGCGCCTGCCCTATC & \multirow{2}{*}{237} & \multirow{2}{*}{ Hozbor et al., 1999} \\
\hline 237BBFla $2 \mathrm{R}$ & AGGCTCCCAAGAGAGAAAGGCTT & & \\
\hline
\end{tabular}


Table 3. Detection of Bordetella bronchiseptica in dogs in relation to their sex and health status

\begin{tabular}{|c|c|c|c|c|c|}
\hline \multicolumn{2}{|c|}{ Antigen detection in dogs } & \multicolumn{3}{c|}{ Positive for detection of B. bronchiseptica with } \\
\hline \multirow{2}{*}{ Sex } & Health Status & Total samples tested & Isolation & Genus specific PCR & Species specific PCR \\
\hline \multirow{2}{*}{ Male } & Sick & 46 & 0 & 1 & 0 \\
\cline { 2 - 6 } & Healthy & 42 & 0 & 1 & 0 \\
\hline \multirow{2}{*}{ Female } & Sick & 23 & 0 & 2 & 2 \\
\cline { 2 - 6 } & Healthy & 36 & 1 & 3 & 1 \\
\hline \multicolumn{2}{|c|}{ Chi-square statistics with respect to } & 0.220 & 0.083 & Species specific PCR \\
\hline \multicolumn{2}{|c|}{ Male: Female } & 0.345 & 0.825 & 0.033 \\
\hline \multicolumn{2}{|c|}{ Sick: Healthy } & 1.000 & 0.948 & 1.000 \\
\hline
\end{tabular}

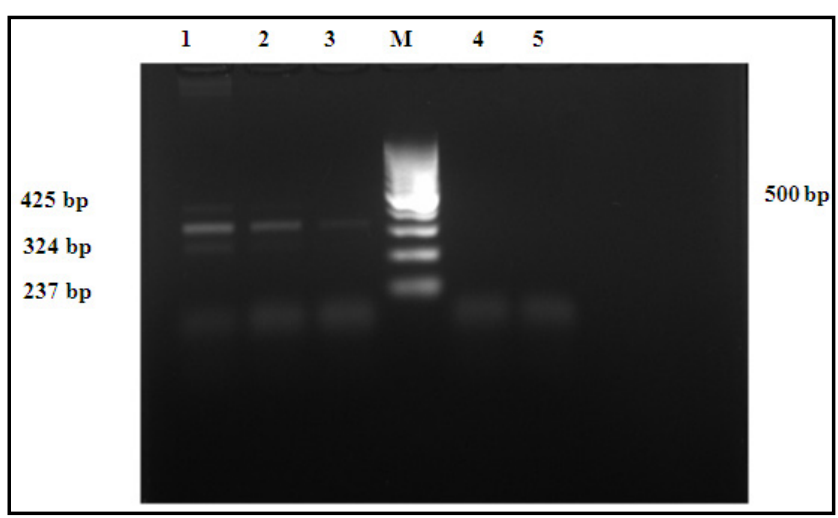

Figure 1. Sensitivity of PCR for Bordetella bronchiseptica using with 10 fold dilution.

Lane M, 100 bp ladder; Lane 1, Positive control (B. bronchiseptica snap chilled supernatant with 500cfu/5 $\mu$ l template); Lane 2, Positive control (B. bronchiseptica snap chilled supernatant DNA with 50cfu/5 $\mu$ template); Lane 3, Positive control (B. bronchiseptica snap chilled supernatant DNA with $5 \mathrm{cfu} / 5 \mu$ template); Lane 4, Positive control (B. bronchiseptica snap chilled supernatant DNA with $0.5 \mathrm{cfu} / 5 \mu \mathrm{l}$ tem; Lane 5 , Positive control (B. bronchiseptica snap chilled supernatant DNA with $0.05 \mathrm{cfu} / 5 \mu \mathrm{l}$ template.

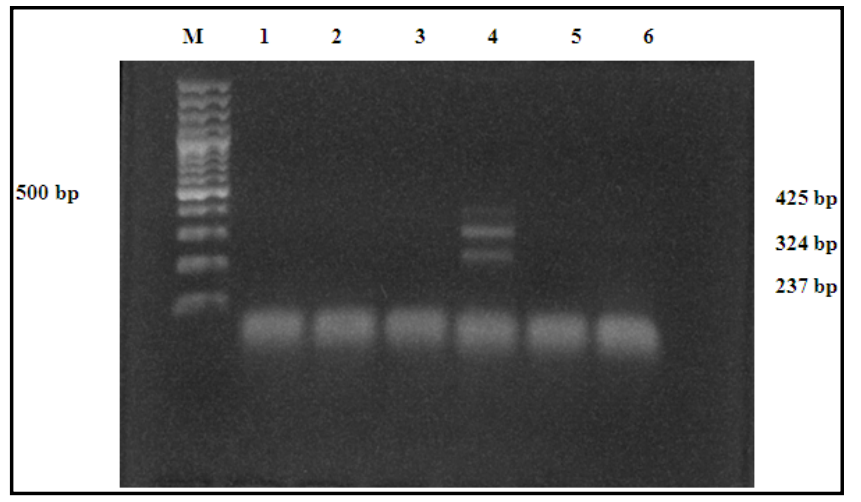

Figure 2. Specificity of PCR for Bordetella bronchiseptica tested with other commonly found respiratory bacteria.

Lane M, 100 bp ladder; Lane 1, E. coli (snap chilled supernatant); Lane 2, Pseudomonas alcaligenes (snap chilled supernatant DNA); Lane 3, Pasteurella multocida (snap chilled supernatant DNA); Lane 4, Positive control (B. bronchiseptica (snap chilled supernatant DNA) Lane 5, Streptococcus pyogenes (snap chilled supernatant DNA); Lane 6, Staphylococcus aureus (snap chilled supernatant DNA). 


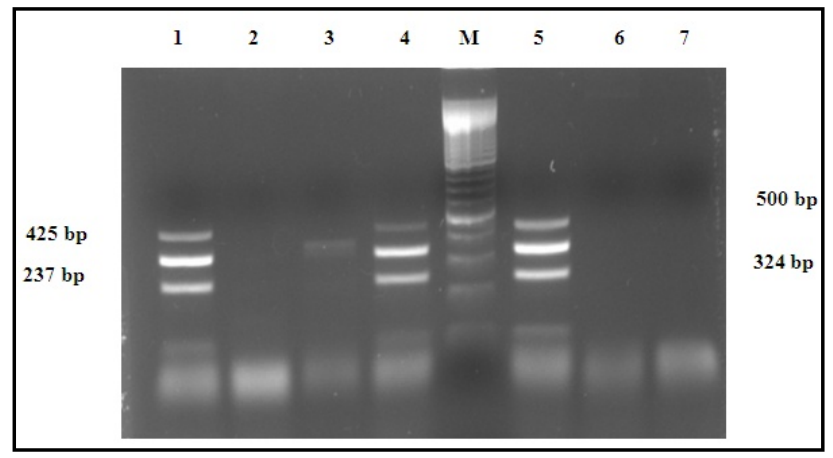

Figure 3. Multiplex PCR for Bordetella bronchiseptica (mPCR) targeting fim(425bp), alc(324bp) and fla(237bp) gene.

Lane M, 100 bp ladder; Lane 1, Positive control (B. bronchiseptica genomic DNA); Lane 2 and 3, Field sample (Snap chilled supernatant); Lane 4, Positive control (B. bronchiseptica snap chilled supernatant DNA); Lane 5, Field isolate of B. bronchiseptica; Lane 6, Field sample (snap chilled supernatant); Lane 7, Negative control.

\section{Results and Discussion}

On processing of nasal and throat swabs from $147 \mathrm{dogs}, B$. bronchiseptica could be isolated from an apparently healthy Labrador bitch aged 14 months from Mumbai but none of sample from sick dogs was positive for the pathogen (Table. 3). In contrast to standard strain, field isolate was sensitive to tetracycline, polymixin-B and nalidixic acid. However, with mPCR, 7 (4.76\%, 4 from healthy dogs and 3 from sick dogs) samples were positive for genus specific amplicon and three (2.04\%, one from healthy and two from sick dogs Labrador bitches) were positive for $B$. bronchiseptica specific amplicons (Fig. 3).

The study revealed (Table. 3 ) that neither the isolation of B. bronchiseptica nor detection of DNA of the pathogen with genus/ species specific PCR had significant association with presence or absence of cough symptoms in dogs ( $p, 0.49)$. However, all the dogs which were positive for $B$. bronchiseptica either through isolation or through $\mathrm{mPCR}$ were all Labrador bitches revealing a significantly more proneness (when results of MPCR were considered final) of females to $B$. bronchiseptica colonization ( $\mathrm{p}, 0.03$ ) however with respect to isolation or detection of pathogen with genus specific PCR no such difference was apparent (Table. 3). In $\mathrm{mPCR}$, one sample each of dogs from Bareilly, Meerut and Mumbai were positive. In dogs below 6 months above two years of age $B$. bronchiseptica could not be detected. More detection of $B$. bronchiseptica in bitches might be instrumental in maintaining the infection in kennels due to more chances of transmission of infection from mother to pups. The positivity for $B$. bronchiseptica antigen was exclusively detected in Labrador bitches which might be due to some unexplored factors associated with more persistence of infection in Labrador bitches.

Low isolation and detection rate of $B$. bronchiseptica from dogs in India was in concurrence to earlier studies on dogs with kennel cough in India [7, 8] and Norway [14]. However in Japan, [15] out of 68 household dogs about 10.3\% samples of dogs were reported positive for B. bronchiseptica. The lower isolation/ detection rate in the study might be due to low prevalence of $B$. bronchiseptica infection in India or due to problems associated with transport of samples over long distances [16]. The study indicated that B. bronchiseptica might not an important cause of kennel cough in India. However, for proving the point, more elaborate studies are needed. Detection of $B$. bronchiseptica by PCR in more number of dogs than isolation indicated that PCR was more sensitive than the conventional method as reported earlier in several studies $[11,12,13,17,18]$. Therefore, multiplex PCR may be recommended for rapid diagnosis of bordetellosis is suspected cases.

\section{Conclusion}

The study revealed that kennel cough had no significant association ( $\mathrm{p}, 0.49)$ with the detection of $B$. bronchiseptica in nasal/ throat swabs of dogs. Further sex (p, 0.03) appeared to be the significant predisposing factors associated with the infection as detection of $B$. bronchiseptica could be isolated and detected with PCR only from the samples taken from bitches. More carriage of infection by bitches may be important factor in maintenance of infection in kennels.

\section{Acknowledgements}

Authors are grateful to Director IVRI, Izatnagar, Joint Director (Academics), IVRI, Izatnagar for providing the fellowship to Monika and Sandeep and funds for undertaking the study. We are also thankful to the dog clinicians who helped to get the samples from dogs suffering with kennel cough and to the dog owners permitting to swab their apparently healthy pet dogs.

\section{REFERENCES}

[1] Appel M and Binn LN. Canine infectious tracheobronchitis. Short review: kennel cough, in: Appel, M.J. (Ed.), Virus infections of carnivores.1987.Elsevier Science Publisher, Amsterdam: 201-211.

[2] Ford RB. Canine infectious tracheobronchitis. In Infectious diseases of the dog and cat. C. E.Greene (ed.). 2006. St. Louis, MO: Saunders Elsevier. 54-61.

[3] Bemis DA, Greisen HA and Appel, MJG. Pathogenesis of canine Bordetellosis. J. Infect. Dis. 1977; 135: 753-762.

[4] Keil DJ and Fenwick B. Role of Bordetella bronchiseptica in infectious tracheobronchitis in dogs. J. Am. Vet. Med. Ass. 1998; 212:200-207.

[5] Harkness JE and Wanger JE. Bordetella bronchiseptica infections. In: The biology and medicine of rabbits and 
rodents. 1995; Baltimore: Williams \& Wilkins, pp 182-185.

[6] Mattoo S and Cherry JD. Molecular pathogenesis, epidemiology and clinical manifestations of respiratory infections due to Bordetella pertussis and other Bordetella subspecies. Clin. Microbiol. Rev. 2005; 18:326-382.

[7] Bonde AV, Sherikar AA and Mulbagal AN. Seroprevalence of Bordetella bronchiseptica and canine parainfluenza virus type 2 in dogs in Bombay. J, Bombay Vet. Col. 1990; 2(2): $79-82$.

[8] Reddy GS, Sharma MSR., Srinivasan VA. Efficacy of inactivated Bordetella bronchiseptica vaccine in mice and dogs. Indian Vet. J. 2003;80(1):1-2.

[9] Singh BR. Labtop for Microbiology Laboratory, ISBN 978-3-8383-1574-40, Lambert Academic Publishing, Germany, 2009.

[10] Quinn PJ, Carter ME, Markey B and Carter GR. Clinical veterinary microbiology. 1994:Wolf Publishing: 280-283.

[11] Register KB, Ackermann MR and Dyer DW. Nonradioactive colony lift-hybridization assay for detection of Bordetella bronchiseptica infection in swine. J. Clin. Microbiol. 1995;33: 2675-2678.

[12] Hozbor D, Fouque F and Guiso N. Detection of Bordetella bronchiseptica by polymerase chain reaction. Res. Microbiol. 1999; 150:333-341.

[13] Xin W, ShiFeng Y and Fang W. Development and application of PCR assay for detection of Bordetella bronchiseptica in rabbits. Pathology and hygiene.2008; $9^{\text {th }}$ World Rabbit Congress:879-1179.

[14] Ueland K. Serological, bacteriological and clinical observations on an outbreak of canine infectious tracheobronchitis in Norway. Vet. Rec. 1990; 126:481-483.

[15] Mochizuki M, Yachi A, Ohshima T, Ohuch A and Ishida T. Etiologic Study of Upper Respiratory Infections of Household Dogs. J. Vet. Med. Sci. 2008; 70(6):563-569.

[16] Halperin SA, Bortolussi R and Wort AJ. Evaluation of culture, immunofluorescence and serology for the diagnosis of pertussis. J. Clin.Microbiol. 1989; 27(4):752-757.

[17] Koidl C, Bozic M, Burmeister A, Hess M, Marth E and Kessler HH. Detection and Differentiation of Bordetella spp. by Real-Time PCR. J. Clin. Microbiol. 2007;45(2): 347-350.

[18] Register KB and Nicholson TL. Misidentification of Bordetella bronchiseptica as Bordetella pertussis using a newly described real-time PCR targeting the pertactin gene. J. Med. Microbiol. 2007; 56:1608-1610. 